ISBN / 978-93-5137-179-3

Ayurlog: National Journal of Reseach in Ayurved Science

\title{
Review of role of jasad bhasma in management of shwetapradar
}

\author{
Snehal Sawant*1, Anjali V. Jadhav²
}

1. PG SCHOLAR (Streerog evum prasutitantra Dept.)

2. Professor, H.O.D \& Guide (Streerog evum prasutitantra Dept.),

College Of Ayurveda and Research Centre., Nighadi, Pune, Maharashtra.

*Corresponding Author: snehalsambhajisawant@gmail.com; 9503580875

\section{Abstract:}

Shwetapradar i.e. Leucorrhoea, also known as vaginal discharge is one of the major problems encountered in gynecological practice. It is a very common condition that has been experienced by most women of all ages especially in child borng reproductive age. It may be due to various causes like pelvic inflammatory disease, fung infections, cervicitis, anemia, diabetesetc. Thedisease mainly has complaints like yonistrav, yonikanađu, yonishula, katishula. Usually, it's a nonpathological symptom secondary to inflammatory conditions of vagina or cervix and wants no medical interventions but it is significant if it is profuse, foul smelling, changed in itscolor and consistency and blood stained. The white discharge is, however caused by the presence of infection in any of these tissues and a variety of other factors.Bhahya andabhyantar chikitsa are described in Ayurveda. In Ayurveda, metal-based preparations, that is, bhasmas are indicated for the treatment of several gynecological diseases. According to Rasa Tarangini, Jasad bhasma is used in management of shwetapradar for its properties.

KEYWORD: Shwetapradar, Yonigatastrav, yonikandu, Jasad bhasma. 


\section{INTRODUTION:}

Women are responsible to create new generation. Under today's circumstances women are bound to undergo ill-health and unhygienic means, that ultimately leads to gynecological problems such as Shwetapradar.

Shwetapradar i.e. yonigata shwetastrav causes great discomfort to women and hamper their normal activities. The pathology of lesion is not as severe as inconvenience is caused. There is common belief that vaginal discharge causes loss of strength and now-a-days ladies possess a fear that it may be due to malignancy. Complaint of yonigata shwetastrav very much depends on one's own idea, power of observation, tolerance etc. The term often used white discharge may be physiological or pathological.

It is physiological in following conditions

- In new born female

- At time of puberty

- At time of ovulation

- During pregnancy

- During coitus

Such physiological conditions don't need treatment.

But pathological condition which necessitate treatment are those involving many infections due to Candida, trichomonas, Gram -ve, gram +ve organism

In Ayurveda Bruhatrayee, has not mentioned Shwetapradar as separate entity, although various conditions giving rise to yonigata shwetastrav has been described. Commentator Chakrapani has explained word pandur asrugdar in his commentary. Many times yonigata shwetastrav is also seen in yonivyapad, yonirog, and sarvadehik vyadhi as a symptom.

Various ayurvedic books have mentioned chikitsa in form of abhyantar or sthanik chikitsa. According to reference of RasaTarangini, Jasad bhasma acts on trayavarta yoni and also acts as shleshmakala sankochak. Jasad bhasma is kaphaghna, pittaghna and balya. It is tikta, katu, kashay rasatmak.

Yonigata shwetastrav symptom is also present in kaphadhikya vyadhi and is also associated with pittadhikya. So aim of treatment is to bring kapha and pitta in normal level. Kashay rasa by virtue of its property does stambhan and is kaphaghna. So it impedes strav.

\section{AIM}

o study role of Jasad bhasma in management of shwetapradar.

\section{OBJECTIVE}

To ensure efficacy of Jasad bhasma by studying its properties and its role in management of Shwetapradar.

\section{MATERIAL:}

1.Books

2. Drug-

\section{Jasad (Zinc)}

- Rasa- Tikta, Kashay, Katu

- Guna-Sheeta

- Karma-Shleshmakala sankochak

- Prabhav-kapha pittahrut

- Swaroopa - Neeli-shweta dhatu 
- Grahya- ujjwala, snigdha, mrudu, drutdrava, mahabhar.

\section{METHODOLOGY:}

\section{INCLUSION CRITERIA:}

- Yonivyapad, yonirog, samanya vyadhi in which yonigata shwetastrav is seen.

- Pathological conditions like infections due to candida, trichomonas, gram -ve, gram +ve organisms are also included.

\section{EXCLUSION CRITERIA:}

- K/C/O Soma roga

- Acquired immune suppressed patients

- Garbhini

- Sutika

- $\mathrm{K} / \mathrm{C} / \mathrm{O}$ - Cervical fibroid /tumor /cyst /CA

3. DOSE $-1 / 2$ to 1 Ratti

4. ANUPAN - Madhu.

5. KALA - Apan kala (Before Lunch and Dinner)

\section{DISCUSSION}

Women's health is considered to be the backbone of the society. Reproductive tract infections are one among the major causes of morbidity in women. Gynecological morbidity in women can range from life threatening diseases such as malignancies to debilitating and psychologically distressing problems such as shwetapradar. Majority of women bear the problems silently without seeking any advice and medical treatment due to shyness, lack of awareness or lack of escort. These disorders have substantial impact on female reproductive ability, mental health and ability to work and perform routine physical activities.Shwetapradar is the most common problem with high incidence seen in reproductive age group women. It is important because besides being a source of distress to the women it may sometimes be the earliest manifestation of some of the major gynecological diseases. It may lead to certain life threatening diseases like cervical cancer and pelvic inflammatory disease. So an early attention towards leucorrhoea as a disease or symptom is helpful. Shwetapradar is a problem which challenges every practitioner today. The infection is difficult to eradicate and recurrence is also frequent. Treatment modality in the allopathic medicine includes antifungal, anti-bacterial, antiprotozoal etc. drugs. Yet the results are unsatisfactory.

In Ayurveda, there is scope to find safe, potent, effective remedy. Previously many herbal drugs or local application has been used for treatment of Shwetapradar, but drug in form of bhasma is rarely used. As patient is in great discomfort due to this yonigata shwetastrav, patient wants quick relief from such discomfort. Drug used in bhasma form gives quick relief than any other treatment, as bhasma has fast absorption rate, it is easy to take and in small quantity. Here action of drug is sthanik samprapti bhanga and patient gets quick relief.

\section{CONCLUSION}

Leuorrhoea is one of the major problems encountered in gynecological practice. It's a common complaint in women of child bearing age and women are less likely to seek treatment for the 
morbidity and thus are more likely to acquire other serious sexually transmitted infections which can prove hazardous for their reproductive life. In such contemporary paradigm when mainstream treatment fails to give rid of leucorrhoea without its recurrence, the Ayurveda's principle based therapy and its medicine 'Jasad Bhasma' plays a pivotal role to give a complete relief to the sufferer. However, infact there is a strong need for creating community awareness about health care facilities and instillself-concern in women for their own health needs.

\section{REFRENCES:}

\section{Ayurvedic Literature-}

1. Prof. Y. G. Joshi, Charaka Samhita, Part-2, Vaidyamitra publication, pune, 1st edition, 2003.

2. Acharya Priyavrat Sharma Sushrut Samhita, part 3, uttar Tantra, Chaukhambha Surbharati publication, reprint 2012.
3. Kashinathshastri, Rasataranginee, Motilal Banarasidas publication, Varanasi, 6th edition, 2009.

4. Shri Brahma Shankar Mishra, Bhava Prakash, part 2 , Chaukhambha Sanskrit Bhavan, Varanasi, 11th edition, 2009.

5. Vaidya Laxmipatishastri, Yogratnakar, Chaukhambha publication, Varanasi, Edition reprint; 2012.

6. Ayurved Sara Sangraha, Shri Baidyanath Ayurved Bhavan Ltd., Nagpur, 18th edition, 1996.

7. Prof. Premvati Tiwari, Ayurvediya Prasuti Tantra avum Streerog, Part-1, Premvati Tiwari, Chaukhambha Prakashan, 2nd edition, 2000.

8. Pratap Kumar, Jeffcott's Principles of Gynecology , Jaypee Brothers Medical publishers (P) ltd., New Delhi, 7th edition, 2008.

9. D.C.Dutta, Textbook of Gynecology, New central Book Agency (P) Ltd, 5th edition 2008.

\section{Cite this article:}

Review of role of jasad bhasma in management of shwetapradar Snehal Sawant, Anjali V. Jadhav

Ayurlog: National Journal of Research in Ayurved Science-2018; 6(2): 1-4 